ACTA UNIVERSITATIS LODZIENSIS

FOLIA LITTERARIA POLONICA 6(44) 2017

http://dx.doi.org/10.18778/1505-9057.44.06

Magdalena Lachman*

Dadaism (Re)activated. Artzins and Dada

There are no closed epochs in art!

Jerzy Tuszewski ${ }^{1}$

\title{
On artzin characteristics
}

An artzin (the term also appears in other spellings: "art-zin", "art zin"; "art zine") ${ }^{2}$ is a private periodical with literary or artistic ambitions published by its creators using their own funds and circulated outside of the official or standard distribution channels (usually via post or a network of mutual exchange, also during concerts, festivals, fan conventions, exchanges, youth events, or sometimes as a supplement to or insert in other periodicals; today, it is also available via the internet). The peak of the presence of artzins in Poland occurred in the 1980s (especially in the second half) and in the early 1990s. They co-formed the so-called "third circulation", a term accepted in research practice in relation to phenomena (such as subcultural prints and magazines, cassette tapes with recordings of music

${ }^{*}$ Magdalena Lachman - Ph.D., works in the Chair of Polish Literature of the $20^{\text {th }}$ and $21^{\text {st }}$ Century at the University of Lodz. She has published on contemporary Polish literature and its connections with mass culture, media and visual culture. She is one of the coordinators of the project Literature and visual arts after 1945 run by the Museum of Modern Art in Lodz (2015-2017). She has published Gry z ,tandeta” w literaturze polskiej po 1989 roku (Playing Trash. Polish Fiction After 1989; Kraków 2004).

${ }^{1} \mathrm{~J}$. Tuszewski, "Co nam zostało z artystyczno-literackiej rewolty dada? Reminiscencje i uwagi z perspektywy bliskiego 100-lecia”, Hybryda, 2014, issue 23, p. 20.

${ }^{2}$ Vide, e.g. entry “Art zine”, [in:] P. Dunin-Wąsowicz, K. Varga, Parnas bis. Stownik literatury polskiej urodzonej po 1960 roku, 3rd edition, Lampa i Iskra Boża, Warsaw 1998, pp. 3-6. Cf. also entry “Art-zin", [in:] W. Pęczak, Mały słownik subkultur młodzieżowych, Semper, Warsaw 1992, p. 10. The use of the most Polonised version of the name (actually already accepted in contemporary communicational practice) is supported by the fact that it has been domesticated in Polish and cultural circles, and its analogy to the spelling of the related "fanzin".

${ }^{3}$ Vide, e.g. entry "Trzeci obieg”, [in:] W. Pęczak, Mały słownik..., pp. 96-97. Cf. also mg [Michał Głowiński], "Trzeci obieg”, [in:] Słownik terminów literackich, J. Sławiński (ed.), Zakład Narodowy im. Ossolińskich, Wrocław-Warsaw-Krakow 1998, p. 593; entry "Trzeci obieg”, [in:] P. Dunin-Wąsowicz, K. Varga, Parnas bis, p. 213; R. Jesswein, “Trzeci obieg”, Odra, 1985, issue 3, 
bands created domestically, graffiti and other forms of urban activity, counter-cultural happenings, etc.) which operated outside official circulation in the People's Republic of Poland (PRL), which was subject to censorship regulations, and, at the same time, did not fit the "second circulation" (or samizdat) of the anti-communist opposition mainly focussed on exposing political issues and motives.

The term itself is a blend of the English: "art magazine" (that is the common interpretation of the term $)^{4}$ or a modification of the name "fanzin"s. The latter etymology better related to the often emphasised desire, common for such anti-periodicals, to create an artistic medium following the example of a fan or subcultural bulletin. Various fanzins and zins with various focusses existed (e.g. music, ecology...), there appeared zins promoting various worldviews and lifestyles (e.g. anarchy, pacifism, vegetarianism; in time, there also appeared feminist zins or similar bulletins of sexual minorities); there are also bulletins by science-fiction literature or comics fans, sports fans, and graffiti artists. ${ }^{6}$ Music fanzins can be considered prototypical for artzins ${ }^{7}$; some, having not evolved into art periodicals, clearly revealed a desire to exert aesthetic influence and offered a chance for their creators

pp. 34-39; B. Głowacki, "Prasa trzeciego obiegu w okresie przełomu”, Kultura-Media - Teologia 2010, issue 3, pp. 33-43.

${ }^{4}$ Vide, e.g. entry "Art zine”, [in:] P. Dunin-Wąsowicz, K. Varga, Parnas bis, p. 3; P. Czapliński, P. Śliwiński, Literatura polska 1976-1998. Przewodnik po prozie i poezji, Wydawnictwo Literackie, Krakow 1999, p. 171; K. Varga, "Trzecia droga, czyli polskie pisma artystyczne w obiegu alternatywnym w latach 80. i 90.”, [in:] Xerofeeria 2.0. Antologia artzinów. Polskie alternatywne pisma literackie 1980-2000. Wersja beta, P. Dunin-Wąsowicz (ed.), Lampa i Iskra Boża, Warsaw 2002, p. 4; J. Ladorucki, "Brulion jako pismo literackie i kulturalne schyłku XX wieku”, Acta Universitatis Lodziensis. Folia Librorum [vol.] 11 (2002), p. 50.

${ }^{5}$ Vide, e.g. K. Puczko, “Zrób to sam”, Ex Libris 1995, issue 83, p. 15; T. Stępień, “Art-zin”, [in:] Szkolny słownik wiedzy o literaturze. Pojęcia - problemy - koncepcje, R. Cudak, M. Pytasz (eds.), Videograf II, Katowice 2000, p. 18; J. Łojas, A. Rogozińska, “Zin”, [in:] Od aforyzmu do zinu. Gatunki twórczości stownej, G. Godlewski, A. Karpowicz, M. Rakoczy, P. Rodak (eds.), Wydawnictwo Uniwersytetu Warszawskiego, Warsaw 2014, p. 560. Bulletins by fans of science-fiction literature are considered as the prototypes of (fan)zins. The name "fanzin" first appeared in those types of publications in the United States in the 1940s (ibid.) The Comet is considered by researchers as the first fan bulletin. It was a magazine published in Chicago in 1930 (vide, e.g. J. Biczyński, "Ziny. Najkrótsze wprowadzenie", Ha!art 2011, issue 35/36, p. 67 and entry "Science fiction fanzine" [on-line], https://en.wikipedia.org/wiki/Science_fiction_fanzine [accessed on: 10.12.2015]).

6 "Motion-picture fans, enthusiasts of unique sexual practices, fans of niche sports, and a large group of unassociated scribblers" all have their own fan bulletins. "The scale of the phenomenon is best visible in the fact that there are bulletins for Christian tattoo aficionados" (J. Biczyński, op. cit., p. 67).

${ }^{7}$ That fanzin history of artzins is strongly supported by P. Dunin-Wąsowicz - vide interview: Donos z czasów bez faktury. O artzinach, poetyce tytułów i wspólnej sieci punkrockerów - z wydawcą, redaktorem naczelnym Lampy i autorem książki Warszawa fantastyczna" - P. Dunin -Wąsowiczem interviewed by A. Wolny-Hamkało, Biuro [Press Office of BWA Wrocław] 2012 issue 1 (issue 4: Lata osiemdziesiate), p. 55. Artzins as mutations of music fanzins were also discussed by, e.g. K. Varga, “Trzecia droga”, p. 4. 
to channel their expressive desires; e.g., there appeared single-page punk bulletins with montage-collage structures, which sometimes included literary texts, mostly stories, as well as drawings, comics and photographs; their trademark were the often individually glued letters cut out from other periodicals ${ }^{8}$, which also became typical for artzins.

Artzins were hand-made, sometimes carefully calligraphed by their creators in a few copies, though usually assembled from previously re-typed texts, reduced in size. Thus, the created paper matrices were later copied using a duplicator or photocopied or printed on risograph; offset productions were very rare. ${ }^{9}$ In time, more and more artzins were created thanks to computers using scanning and further processing offered by computer graphics suites, which in the view of many commentators negatively influenced the appearance of zins, which lost their spontaneous and garage/hand-made nature, which had been considered their trademark.

Artistic zins were created by single people or collectives without defining traditional editorial structures with the function of an editor-in-chief or people responsible for specific issues. Artzins were published in small numbers of copies (circulations would rarely reach the level of five hundred copies, usually they did not exceed one hundred copies, and sometimes they consisted of twenty to thirty or even fewer), often irregularly (there occurred single-issue works), and in a short-term manner (after publishing several consecutive issues periodicals would terminate or their publishers changed their titles and specific forms). The

${ }^{8}$ The practice referred to the techniques used by the representatives of the Western subcultural music community (glued letters or the styling of the type of graphic solutions appeared not only in fanzins but also on music record covers) and was supposed to emphasise the hand-made manner of producing zins, and, at the same time, it constituted an antidote to the printing monotony and graphic shortcomings of the prints of the PRL and second circulation. NB, the same may be said of the evocative arrangement of font in the name of bruLion, a leading generation literary and cultural journal of the 1980s and 90s, which, even if not featuring a completely alternative pedigree, offered a distinct inclination towards counter-cultural gestures. It's easy to recognise that the visual form present on the cover from the very first issue of bruLion was a result of the collage idea of the editors who cut individual letters from the titles of various Polish periodicals and newspapers (more precisely from: Trybuna Ludu, Znak, Krakow-based Pismo, Zeszyty Literackie, London-based Puls, and Paris-based Kultura) published in the 1980s. That operation, on the one hand, through its ingenuity, compensated for the lack of technical capabilities of utilising more sophisticated graphic solutions during the times of the PRL's shortages of almost everything and, on the other, starting with the visual layer, it manifested its planned autonomy, and opposing approach or distrust towards the contemporary ideological proposals; it indicated the need to express original opinions in the face of the (non-)negotiable conglomerate of the existing discourses, narratives, and thoughts. The history of the lettering of the name bruLion was traced by R. Tekieli, the journal's editor-in-chief, in interviews with him, e.g. in a programme broadcast by Polish Television in the mid-1990s hosted by Maciej Orłoś entitled Oko w oko. Cf. also J. Ladorucki, op. cit., p. 61.

${ }^{9}$ For a more detailed discussion of the issues, vide P. Dunin-Wąsowicz, "Donos z czasów bez faktury", pp. 55-57. 
scale of the phenomenon was striking. Based on various sources, researchers estimate that in total in Poland since the 1980s there have appeared at least one hundred ${ }^{10}$, and it is assumed around two hundred ${ }^{11}$ (if one also considers the 1990s and contemporary internet circulation) similar projects.

Artzins functioned in closed circulation and had fixed groups of receivers who usually paid small fees and remained in contact with the creators, often sending letters to them, which were sometimes published in bulletins (in the readers' section - even fake and mocking ones constituted an important element of many bulletin productions of that type). ${ }^{12}$ Therefore, one could talk about the interchangeability of the roles of senders and receivers, which was actually typical for the third circulation and for counter-cultural initiatives. The creators also confronted their receivers during festivals and exhibitions (in November 1989 in Łódź, Krzysztof Skiba organised Wystawa Prasy Alternatywnej (Exhibition of Alternative Press), also known as: Wystawa Prasy Zajebistej (Exhibition of Out-fucking-standing Press) or Wystawa Polskiej Prasy Zajebistej (Exhibition of Out-fucking-standing Polish Press) under the banner of: Szalona Twórczość Xeroksów (Crazy Xerox Creations) ${ }^{13}$, and conventions of the creators of those samizdat bulletins. Such meetings were held in the mid-1990s in Zielona Gora (through the initiative of Jacek Katos Katarzyński) ${ }^{14}$ and in Warsaw under the patronage of Staromiejski

${ }^{10}$ Vide entry “Art zine”, [in:] P. Dunin-Wąsowicz, K. Varga, Parnas bis, p. 5.

${ }^{11}$ P. Dunin-Wąsowicz, "Jak zakwitly i zwiędły kwiaty technologii i demokracji - artziny w Polsce”, [in:] Kultura niezależna w Polsce 1989-2009, P. Marecki (ed.), Korporacja Ha!art, Krakow 2010, p. 49.

${ }^{12}$ When interpreting the phenomenon of zins, researchers sometimes stressed that one of their major allures was the intimate nature of the contact with the readers (cf., e.g. J. Ladorucki, op. cit., p. 51). It seems, however, that for such initiatives, the key element was the act of creation, of selecting the specific form of expression.

${ }^{13}$ Vide K. Skiba, Komisariat naszym domem. Pomarańczowa historia, 2nd edition, Narodowe Centrum Kultury, Warsaw 2015, pp. 178-187 and photograph on p. 203. Information on a planned exhibition could be found in Krzysztof Skiba's humorous zin, which was a division of the Łódź-based Orange Alternative and Alternative Society Movement (Ruch Społeczeństwa Alternatywnego), Przegięcie Paty, 1989, issue, p. 3 - I am using a digital version available at Zielona Góra Digital Library: http://zbc.uz.zgora.pl/dlibra/plain-content?id=20552, [accessed on: 10.12.2015]. Cf. also, e.g. entry "Czerwony Kapturek", [in:] P. Dunin-Wąsowicz, K. Varga, Parnas bis, p. 34 (the entry includes a mistake which states that Wystawa Prasy Zajebistej was held in the winter of 1989; actually, it started on 24 November 1989 and lasted one week - cf. K. Skiba, op. cit., pp. 181-182). The mistake was also included in A. Kamińska, "Art-ziny. Zielonogórska twórczość alternatywna lat 90.”, [in:] Kultura i spoleczeństwo na Środkowym Nadodrzu w XIX i XX wieku, P. Bartkowiak, D. Kotlarek (eds.), Pro Libris - Wydawnictwo WiMBP im. Cypriana Norwida w Zielonej Górze, Zielona Góra 2008, p. 146 (note 52 - not 1991, should be 1989).

${ }^{14}$ Vide entries: “Art Zine Gallery”, “Art Zine Kongres”, [in:] P. Dunin-Wąsowicz, K. Varga, Parnas bis, p. 6., and catalogue: Art-ziny. Zielonogórska twórczość alternatywna lat 90. [exhibition catalogue: Muzeum Ziemi Lubuskiej w Zielonej Górze, IX-X 2009, exhibition concept and program, catalogue content: A. Kamińska, consultants: J. Katos Katarzyński, B. A. Kieć] Muzeum Ziemi Lubuskiej, Zielona Góra 2009. Cf. also K. Varga, "Trzecia droga”, p. 11-12; J. Sobczak, 
Dom Kultury (and coordinated by Krzysztof Varga and Paweł Dunin-Wąsowicz). ${ }^{15}$ They were accompanied by fashion shows (referred to as "futuristic"), screenings of films developed by independent creators (usually parodies of action films) ${ }^{16}$, rock concerts, exchanges, and discussions of similar or satellite projects in the area of (counter-)culture, e.g. meetings regarding graffiti or exhibitions of plastic art. Alongside them, there were published anthologies and catalogues. ${ }^{17}$ The tradition of those meetings has been revived in recent years in the form of micro-festivals and zin fairs. ${ }^{18}$

"O Art Zine Gallery i Art Zine Kongres”, [in:] “Arkusz literacki”, Informator Kulturalny Województwa Zielonogórskiego, 1997, issue 6; A. Kamińska, "Art-ziny”, op. cit., pp. 144-148; R. Rudiak, "Literacka promocja Zielonej Góry pod koniec XX wieku, czyli historia zjawisk artystycznych i wydarzeń kulturalnych", Studia Zielonogórskie, vol. 19 (2013), pp. 68-75; R. Rudiak, "Trzeci obieg literatury. Artziny w Zielonej Górze i w województwie", [in:] Życie literackie na Ziemi Lubuskiej w latach 1945-2000, Pro Libris, Zielona Góra 2015, pp. 284-288. Summaries of specific meetings were included in the following texts: P. Dunin-Wąsowicz, R. Smoczyński, "Zlot awangardy i ariergardy w Zielonej Górze", Życie Warszawy, 1992, issue 239, p. 13; R. Smoczyński, "Przyspieszyć koniec świata", [in:] Żadna rozrywka dla chłopaków, Lampa i Iskra Boża, Warsaw 1993, pp. 12-20; Z. Haczek, “Art-zine: głos spod ziemi”, Gazeta Lubuska, 1992, issue 238, p. 13; J. Katarzyński, "Kalejdoskop przypadków czyli Art Zine Gallery”, Krzywe Koło Literatury, 1994, issue 5 pp. 8-11; K. Varga, "Zinowcy są zmęczeni”, Gazeta Wyborcza, 1994, issue 250, p. 10.

${ }^{15}$ Vide entry “Art Zine Show”, [in:] P. Dunin-Wąsowicz, K. Varga, Parnas bis, p. 6. Cf. also K. Varga, "Trzecia droga”, pp. 11-12; L. Żuliński, “Art Zine Show”, Wiadomości Kulturalne, 1995, issue 25, p. 4; Ł. Klesyk, "Koniec czasu utopii”, Wiadomości Kulturalne, 1995, issue 25, p. 4. Discussions of the Art Zine Show were also included in Krzywe Koło Literatury - vide "Drugi Warszawski Art Zine Show 20-21 maja 1994”, Krzywe Koło Literatury, 1994, issue 5 p. 6-7; “Art Zine Show - festiwal poświęcony młodej «undergroundowej» literaturze (1995) III: Warszawa, $20 \mathrm{~V}$ 1995, Staromiejski Dom Kultury i Stowarzyszenie Przyjaciół Akademii Ruchu”, Krzywe Koło Literatury, 1995, issue 4 p. 15; Krzywe Kolo Literatury, 1995, issue 7 [June/July] pp. 2-11.

${ }^{16}$ K. Varga, "Trzecia droga", p. 11.

${ }^{17}$ Vide Art Zine Gallery [catalogue of the 1st Art Zine Gallery festival], Zielona Góra 1992; Xerofeeria. Antologia. Polskie alternatywne pisma artystyczne od $-\infty$ do października 1993. Antologia Art Zinów. - Wyd. dla Art Zine Gallery II, P. Dunin-Wąsowicz, J. Katarzyński, J. Sobczak, A. Wasilkowski (eds.), Lampa i Iskra Boża, Warsaw-Zielona Góra 1993; Xerofrenia. Antologia wierszy z tomików wydawanych $w$ obiegu alternatywnym i nie tylko. Antologia nowych wierszy Wyd. dla Art Zine Gallery III, selection of poems P. Dunin-Wąsowicz, J. Sobczak, drawings by Kain May, Lampa i Iskra Boża, Warsaw-Zielona Góra 1994; Xerofuria. Antologia-katalog. III warszawski Art Zine Show, 20 maja 1995, editing, introduction and notes: P. Dunin-Wąsowicz, Staromiejski Dom Kultury, Warsaw 1995. Cf. also P. Dunin-Wąsowicz, K. Varga, Parnas bis, pp. 227-228; R. Rudiak, Literacka promocja..., pp. 68-78.

${ }^{18}$ E.g. on 26 November 2011 the Warsaw $1500 \mathrm{~m}^{2}$ club hosted a zin, self-publishing and design fair, and a celebration of the second anniversary of the Kofeina zin - I am quoting an unsigned note by J. Bińczycki, "Mikrofestyn", Ha!art 2011, issue 35/36, p. 80. In Warsaw, two editions of the Drukuj! Zinfest festival were held - the first on 20 September 2015 at Klubokawiarnia Chmury, the other on 24 January 2016 in V5 gallery - vide, e.g. E. Dłużewska, "Drukuj w galerii, obejrzyj historyczne ziny”, Gazeta Wyborcza. Warszawa, 20.01.2016, [on-line], http://warszawa.wyborcza.pl/warszawa/1,34862,19502611,drukuj-w-galerii-obejrzyj-historyczne-ziny.html [accessed on: 25.02.2016]. 
Attempts at systematising the approaches to artzins bear various research problems. First of all, there is a problem with accessibility (one can often experience only second-hand artzin productions - in anthologies, reprints, and discussions or descriptions); secondly, there is a problem with their non-stable reception and semantics ${ }^{19}$; thirdly, a problem with establishing a satisfactory research focus. The problems with researching artzins and finding an appropriate language of description for them has been indicated by various commentators ("I was not able to find a way to describe the phenomenon for a long time" ${ }^{20}$ ), usually relying on cataloguing, anthologising, reporting on and developing encyclopaedic approaches to the bulletin-based phenomenon, including quoting basic studies devoted to $i^{21}$, and utilising elementary factography (often mechanically developing second-hand copies without verifying the sources of the information provided), sometimes venturing to create pastiche forms ${ }^{22}$ as the most fitting manner of coping with the topic. Nonetheless, what is also worth mentioning is the boom in the field of (art)zin diagnostics. In recent years, the number of texts on those anti-periodicals has been steadily increasing (similarly to the discussions and works on the Polish counter-culture of the 1980s and the early-1990s). ${ }^{23}$

How are artzins perceived and who analyses them? The dominant approach is the sociological one (artzins are often considered as an expression of youth

\footnotetext{
${ }^{19}$ E.g. the terms "artzin" and "fanzin" may possess slightly different meanings depending on the person who uses them - that was indicated by P. Dunin-Wąsowicz, "Donos z czasów bez faktury”, p. 55. Cf. ibid. "Jak zakwitty...”, pp. 48-49.

${ }^{20}$ J. Bińczycki, “Zin o zinach”, Ha! art, 2011, issue 35/36, p. 66.

${ }^{21}$ Vide P. Czapliński, P. Śliwiński, op. cit., pp. 169-173 (especially pp. 170-172).

${ }^{22}$ Vide “Zin o zinach", J. Bińczycki (ed.), Ha!art, 2011, issue 35/36, pp. 65-80.

${ }^{23} \mathrm{Cf}$. the bibliography attached to the article. Today, the importance of internet databases, websites and forums devoted to zins is increasing. There is also a tendency to digitalise them - vide especially the website: www.zinelibrary.pl The high interest in the topic has also been proven by the re-editions of studies devoted to it, e.g. recently, there was a reprint of a text by R. Tekieli, "Fuckty (1)", bruLion, 1989, issue 11-12, pp. 148-168 - vide R. Tekieli, "Fuckty" [reprint with the consent of R. Tekieli, edited and abbreviated by: M. K. Dziób], Fronda LUX 2014, issue 72; there are also ongoing works on an encyclopaedia of Polish zins - as an updated version of the book: D. Ciosmak, Antologia zinów 1989-2001, Wydawnictwo Liberation, Kielce 2001 (contrary to what the title might suggest, the publication was not an anthology, rather an encyclopaedia with an entry -based structure presenting various profiled zins, e.g. comics, literary, or music-focussed, created in the Polish hard core/punk/reggae, or "freedom" communities, and those created by anarchistic or pacifistic groups). Master's and Bachelor's theses are being written on zins, and zins are displayed in exhibitions (vide catalogue: Art-ziny. Zielonogórska twórczość alternatywna lat 90., op. cit.). Artzins are also discussed when approaching broader notions, e.g. the literary life or the press output of a specific region (e.g. Kultura i spoleczeństwo na Środkowym Nadodrzu..., pp. 137-148; R. Rudiak, Życie literackie na Ziemi Lubuskiej..., pp. 284-288, 296-299) or genres of oral works (Od aforyzmu do zinu..., pp. 560-569). Additionally, artzins are currently being collected not only by private collectors but are also often included in the collections of libraries and museums (a considerable collection of those is kept by, e.g. the Museum of the Lubuskie).
} 
rebelling and are defined when discussing alternative culture models or subcultural initiatives) ${ }^{24}$. There sometimes appear press-science or library-science approaches. ${ }^{25}$ At times, museum-science ${ }^{26}$ or linguistic ${ }^{27}$ approaches are favoured. An important role is also played by journalistic-reporter or memoir commentaries made by people personally engaged in that type of publishing movement (or in subcultural initiatives in general) - from the publishing or stimulation side, or by fans of the phenomenon (the available, especially in the internet, spontaneous studies often display a creed nature $\left.{ }^{28}\right)$.

\section{Press art, or artzins of the arts}

Even though researchers have identified in artzins (rather through a hunch than some more extensive analyses) "a sign of the new times, new language, and new motivations in art"29, in their assessments they mainly emphasise the fact that artzins constituted a spontaneous form of expression and a result of amateur activities, a model realisation of the do it yourself principle. However, it would be unwise to detach artzins from their art-based circumstances, as they were often a result of those or they constituted an important point of reference for those press projects (NB, resonating even in their very name; in fact, the $D I Y$ principle can be considered as a practical application of the motto: "everyone's an artist", representative for the programmes of the easily recognisable 20th-century avant-garde movements).

${ }^{24}$ Vide, e.g. M. Jędrzejewski, "Fanziny i artziny”, [in:] Młodzież a subkultury. Problematyka edukacyjna, Wydawnictwo Akademickie „Żak”, Warsaw 1999, pp. 215-224; M. Pęczak, “Alternatywne komunikowanie", [in:] Spontaniczna kultura młodzieżowa. Wybrane zjawiska, J. Wertenstein-Żuławski, M. Pęczak (eds.), Wydawnictwo „Wiedza o Kulturze”, Wrocław 1991, pp. 199-216.

${ }^{25}$ Vide A. Firlej-Buzon, "Historia polskich fanzinów", Acta Universitatis Wratislaviensis. Bibliotekoznawstwo [vol.] 21 (1998), pp. 45-56; J. Ladorucki, op. cit., pp. 50-53.

${ }^{26}$ Vide catalogue: Art-ziny. Zielonogórska twórczość alternatywna lat 90.

${ }^{27}$ Vide, e.g. M. Idzikowska, "O pewnej osobliwości nazewniczej - tytuły zinów”, Filologia Polska [vol.] 3 (2007), pp. 43-59 [monographic issue: Między słowem a obrazem, K. Smużniak (ed.), Wydawnictwo Uniwersytetu Zielonogórskiego, Zielona Góra 2007]. Cf. also W. Kajtoch, Świat prasy alternatywnej $w$ zwierciadle jej stownictwa, Wydawnictwo Uniwersytetu Jagiellońskiego, Krakow 1999 - the author, in fact, excluded from his study "literary zins", as he called them, stating that they offer a special linguistic arrangement specific for aesthetic influence (ibid., p. 9), but even that gesture carried significance and indirectly indicated the typical verbal and structural properties of zins.

${ }^{28}$ Vide, e.g. K. Kaim, Niezależny III obieg literacki w Polsce, http://www.siemysli.info.ke/niezalezny-iii-obieg-literacki-w-polsce/ [accessed on: 10.12.2015]: "When in 1988, I first came across a third-circulation publication, I was extremely surprised that something like that even existed. I was only 14 and quite rebellious towards that reality. I remember that it was »Azotox« [...] published independently by young people in the Dezerter band. [...] It was my first zine (read as zin) and then I started to seek out others. I still read and collect them, though everything has changed so much.”

${ }^{29}$ P. Czapliński, P. Śliwiński, op. cit., p. 171. 
The patterns and contexts in which artzins are located are distributed broadly. They are considered through analogy as forms of school bulletins or boyish student jokes or treated as productions with a social character or amateur works ${ }^{30}$. Researchers also identify in them associations to all types of ephemera. They are also placed in the context of "urban folk" ${ }^{31}$. They are considered as contemporary versions of picaresque literature ${ }^{32}$. Sometimes they are perceived through references to naive art or the works of naive painters ${ }^{33}$ or bricolage strategies ${ }^{34}$. It is often the case, something I have already mentioned, that researchers emphasise artzins' genetic founding in fanzins and other outcrops of alternative culture (interestingly enough, they stress that Polish artzins are closer to American counter-cultural fanzins than to the typical samizdat ${ }^{35}$; they also indicate similarities with subcultural bulletins of British punks and their fans, American hippies, and Dutch provos ${ }^{36}$ ). Furthermore, they stress the relation of artzins to mail-art ${ }^{37}$ or the Beatnik principle of chapbooks $^{38}$. They even raise the distant though significant patronage of such periodicals as the modernist Chimera edited by Zenon Przesmycki and Zdrój, the Poznań-based body of Polish expressionists ${ }^{39}$. Finally, they emphasise the similarities with futurist one-day bulletins, Dadaist and Surrealist periodicals, and other programme prints and publications of the representatives of the 20th-century avant-garde. Piotr Gradowski, publisher of the polE artzin published since 2009, strongly emphasised those final similarities and considered as artzin prototypes (or entities possessing in the past identical goals) the London-based Vorticist Blast (1914-1915), the New York-based Dadaistic 291 (1915-1916) and the Zurich-based Dada (1917-1919), the Paris-based La Révolution surréaliste by André Breton (1924-1929), and the Interview by Andy Warhol (created in 1969 and circulated among the visitors to The Factory), prints of the Fluxus movement (authored by, e.g. Dick Higgins' Something Else Press),

${ }^{30}$ Vide, e.g. M. Pęczak, “Amatorzy awangardy”, Polityka, 1993, issue 47, p. 10.

${ }^{31}$ K. Varga, "Trzecia droga", pp. 9-10.

32 Vide P. Rypson, “Dosyć Podporządku!”, Ex Libris, 1994, issue 43, pp. 10-11.

${ }^{33}$ K. Varga, "Trzecia droga", pp. 9-10.

34 Ibid.

${ }^{35}$ Ibid. Researchers emphasised the similarities of Polish artzins with, e.g. the New York-based Stroker magazine - vide, e.g. entry "Art-zin”, [in:] M. Pęczak, Mały słownik..., p. 10. Cf. also M. Schneck, Historia zinów, zinelibrary.pl [on-line], http://zinelibrary.pl/index.php?option=com content\&view=article\&id=159:historia-zinow\&catid=11:o-zinach\&Itemid=3\#_ftn25 [accessed on: 10.12.2015]; J. Bińczycki, Ziny, pp. 67-68.

${ }^{36}$ Vide entry "Fanzin", [in:] M. Pęczak, Mały słownik..., p. 25.

${ }^{37}$ P. Rypson, op. cit., pp. 10-11; K. Puczko, op. cit., p. 15; K. Varga, "Trzecia droga”, p. 5.

${ }^{38}$ M. Schneck, op. cit. Vide also F. Wright, The History and Characteristics of Zines, [on-line], http://zinelibrary.pl/index.php?option=com_content\&view=article\&id=191\%3A-fred-wright-the -history-and-characteristics-of-zines $\&$ catid= $11 \% 3$ Ao-zinach \&Itemid=3\&limitstart $=1$ [accessed on: 10.12.2015].

${ }^{39}$ K. Varga, "Trzecia droga", p. 4. 
bulletin productions of Maurizio Cattelan, i.e. Toilet Paper, a surrealist photography periodical authored by him, as well as Charley and Permanent Food ${ }^{40}$. Upon employing such an approach, artzins clearly become "mediums of creative stimuli" ${ }^{41}$ and the realisations of the principle of press art. ${ }^{42}$ In fact, artzins can be treated not only as carriers of literary content or transmitters of specific literary-plastic solutions, but also as integral aesthetic objects, types of embodiments of press art. In other words, they are worth considering as fully fledged artistic facts or at least one should assume that they aspire implicite to be situated in the art realm ${ }^{43}$ (especially if one considers them as consistently developed newspaper parodies ${ }^{44}$ ). One characteristic feature of the nature of artzins was and, in my opinion, still is not as much its amateur character (that applies to artzins as if by default), but the principles of the freedom of creating and developing them "freely, without institutionalisation" 45 , and before 1989, outside of censorship and any organisation and distribution structures or without the necessary state-issued permits; later, without registration, invoices and meeting any legal requirements which an official periodical must do, and yet with ambitions, through the (anti-)press medium, to achieve artistic fulfilment, accidentally or intentionally promote own vision of culture, directly or indirectly reveal the limitations and consequences of specific principles, questioning the stable, obvious, and unalterable nature of the applicable convictions (e.g. regarding the informative function of a newspaper, the general literary rules, the status of a written text, the hallmarks of art...), intuitively or with a high level of self-awareness (and often humour) stating one's own artistic programme which is reached methodically or instinctively. ${ }^{46}$

The artistic nature of artzins is emphasised by several issues. Their creators clearly stated their intentions: "We create something which we consider art and which deserves appropriate presentation. The most available form of propagation for us is the written word, therefore, we decided to create a newspaper where it

${ }^{40}$ P. Grabowski, “Zrób sobie dobrze zin. Od niezależności jako idei do niezależności jako formy”, Res Publica Nowa, 2011, issue 16, pp. 67-68.

${ }^{41}$ Ibid., p. 66.

${ }^{42}$ I used the term differently than Grzegorz Sztabiński, whose article made me realise the operative utility of the term (vide G. Sztabiński, "Idea PRESS ART”, Tygiel Kultury, 2000, issue 11/12, pp. 39-43). I am not referring to practising art through newspapers but to the ability to consider periodicals as artistic artefacts.

${ }^{43} \mathrm{Cf}$. also the opinion of J. Kajtoch regarding the future of zins: "I believe that zins will function as works of art created by small groups of people" ("Nowa epoka w stanie pierwiastkowym. Rozmowa z Wojciechem Kajtochem”, interview by J. Bińczycki, Ha!art, 2011, issue 35/36, p. 75).

${ }^{44}$ A proposal for discussing zins within those categories is offered in: M. Pęczak, "Alternatywne komunikowanie", p. 214.

${ }^{45}$ P. Dunin-Wąsowicz, "Donos z czasów bez faktury”, p. 56.

${ }^{46}$ Basically, the only instance where I see differences between specific artzins is in the intuitive or methodical approach and the degree of artistic self-awareness. They do share, though, the ambition to place themselves within the art realm. 
will be possible to fully present our works." ${ }^{97}$ Artzins often constituted bodies of literary or art groups, e.g. the Warsaw-based Linie was a body of Słoneczna Ekipa Tworząca and the members of Joanna Makabresku's band (even the subtitle of the artzin indicated that: Nasiąnięty organ Joanny Makabresku (Joanna Makabresku's Saturated Body)); Exkluziv was both the name of an artzin published in Częstochowa and a literary group established in the city by students of Polish studies; the single-person Grópa Obłęd consisted of Wojciech Maria Koronkiewicz, who was also active in the Białystok samizdat forum; the artzin-rooted Lampa i Iskra Boża was endorsed by Zjednoczone Oficyny Odlotystów represented by Paweł Dunin-Wąsowicz and Andrzej Stefan Rodys; Gangrena, Futurfoto and Higiena, and later Metafizyka Społeczna were subsidiaries of Totart. In those anti-periodicals, authors who operated in the art industry fulfilled their various ambitions. In fact, some of them made their mark in the official literary market by publishing books in official circulation; the same also applied to representatives of the plastic arts: Paweł Dunin-Wąsowicz remarked that the first person he met who developed artzin-fanzin collages was the, at that time, sixteen-year-old Maurycy Gomulicki ${ }^{48}$.

The placement of literary zins within the realm of art has the added advantage that it brings them closer to similar initiatives often undertaken in Poland in the 1980s and $90 \mathrm{~s}$ by visual artists. Thus, the correlation with such undeniable artistic undertakings as Tango by Łódź Kaliska, Halo Haloo, Hola Hoop, Hala Gala by Jacek Kryszkowski, Oj, dobrze już by Gruppa, bulletins of the Wrocław -based group Luxus, Tygodnik Leeeżeć by the Lódź-based happenning Wspólnota Leeeżeć or Stynne Pismo we Wtorek published by the Krakow-based Grupa Ładnie can become clear ${ }^{49}$ (though there is a trend to define and separate those initiatives from typical artzin productions created to present the achievements and

${ }^{47}$ A.K. [Aleksander Kaczorowski], “Czyżby Agonia Uczuć' 1987”, issue 1 (emphasis based on original entry). As cited in: Xerofeeria 2.0., op. cit., p. 47. The introduction to an artzin published in 1987-1988 in Grodzisk Mazowiecki bearing the style of a manifesto established by local high school students: Aleksander Kaczorowski and Tomasz Karoń, was also referenced by P. Dunin-Wąsowicz, "Jak zakwitly...", pp. 55-56. The quoted author is today a well-known literary personality - a journalist, translator, specialist in Czech literature and culture, and a writer and biographer, with many books to his name, e.g.: Praski elementarz (2001), Praskie łowy (2007), Ballada o kapciach (2012), Gra o życie. Opowieść o Bohumilu Hrabalu (2004), Havel. Zemsta bezsilnych (2014), Hrabal. Stodka apokalipsa (2016).

${ }^{48}$ P. Dunin-Wąsowicz, "Donos z czasów bez faktury”, p. 55.

${ }^{49}$ Further discussions of artzins and zin-like prints of the indicated art groups and creators, vide, i.a. P. Rypson, "Stan wojenny i inne stany”, [in:] Ksiązki i strony. Polska ksiażka awangardowa i artystyczna w XX wieku, Centrum Sztuki Współczesnej, Warsaw 2000, pp. 124-136; A. Mituś, P. Stasiowski, P. Rypson, Agresywna niewinność. Historia grupy Luxus, BWA Wrocław\&Osman Djajadisastra, Wrocław 2014, i.a. pp. 121-216, 425-440; M. Drągowska, D. Kuryłek, E. M. Tatar, Krótka historia Grupy Ładnie, Korporacja Ha!art, Krakow 2008, especially pp. 78-86. 
writing skills of their authors ${ }^{50}$, I would intuitively seek a method to see them in a similar place and find a consolidating narrative for them ${ }^{51}$ ).

In the creation and description of artzins it seems that what is important is generally the search for common denominators and the reconstruction of their underlying global strategies (artzins possess a collective significance, amplify each other, thus creating the phenomenon; that is why it is better to view them collectively as a result of specific expressive needs than discuss them in isolation). In their case, what is significant is the very act of and compulsion to create (e.g. this is what the members of Słoneczna Ekipa Tworzaca and the publishers of the Linie artzin said about their motivations for creating it: "There had to form such a field where you put something you create at home. So that it does not elude you"52), as well as the need to transmit their artistic programme via the press medium and the will to exert aesthetic influence on the receivers, which is expressed in, e.g. the attention to the graphic design and the visual dynamics of the publications. In fact, they were known for often having quite elaborate, for DIY capabilities, typographic solutions. Artzin pages were, e.g. singed (which not only made them even more interesting, but also offered a chance to interpret the effect in terms of artistic semantics); sometimes the covers were made of a specific material, e.g. out of cardboard egg packaging (which was supposed to amplify their ludic message and content). ${ }^{53}$ There was an obvious drive towards giving specific issues unique characteristics, e.g. the sixth issue of Linie was published on a black (or in bibliophile copies: navy blue) background. ${ }^{4}$ "Each copy of one of the issues of the «Żaden» zin from Szczawno Zdrój was decorated differently: with a few paint strikes on the cover." 55 Patison (Dariusz Patison, aka Dariusz Śmiech), publisher of Xero, specialised in mocking covers and supplements, e.g. he created the fifth issue of Xero "with a glued on piece of metal of the 10,5 beer can" 56 , the third issue of Xero included a pierced condom with an invitation to "play something like Russian roulette" 57 ; the publication also had some wild pagination, consecutive pages had numbers assigned without any apparent order: $39,183,60,37,6,12,666^{58}$. Also, "to create the cover of [...]

${ }^{50}$ Vide, e.g. P. Dunin-Wąsowicz, “Technologia i ośmielenie”, [in:] Xerofeeria 2.0, p. 3.

${ }^{51}$ Even more so, since in the case of artbooks or newspaper artistic artefacts produced by the representatives of visual arts, researchers also often use the term "artzin", and sometimes make classic artzins reference points for that type of publications - vide, e.g. remarks in Luxus: A. Mituś, P. Stasiowski, P. Rypson, op. cit., pp. 29-31, 134, 149, 162.

${ }^{52}$ Słoneczna Ekipa Tworząca, “Żeby nie uciekało”, [in:] P. Dunin-Wąsowicz, Rozmowy Lampowe 1993-2007, Lampa i Iskra Boża, Warsaw 2007, p. 17.

${ }^{53}$ P. Dunin-Wąsowicz, "Donos z czasów bez faktury”, p. 56.

${ }^{54}$ Słoneczna Ekipa Tworząca, op. cit., p. 17.

${ }^{55}$ P. Dunin-Wąsowicz, "Donos z czasów bez faktury”, p. 56.

${ }^{56}$ Ibid.

${ }^{57}$ K. Varga, "Trzecia droga”, p. 9.

${ }^{58} \mathrm{Ibid}$. 
«Luzjub Urłałcz» (its author asked his friends to provide one syllable each which he later compiled at random and thus created the cryptic title), the author used a razor, chocolate packaging, and several small nails." ${ }^{59}$ One of the issues of Tytut was created by Jan Sobczak, its publisher, in such a way that its pages became smaller towards its middle, and later grew to return to their initial dimensions. In the middle, there was dried parsley. ${ }^{60}$ Issue 9 of Tytut called Tytut hermetyczny (Air-tight Title) was glued using the universal hemol glue, thus preventing the reading of the air-tight contents announced on the cover. ${ }^{61}$ Sobczak also experimented with the format and published issue 11, the final issue, in the form of loose A4 sheets and attached a cassette recording with instructions on how to handle the magazine and a recording of him reading literary works - his favourite ones and his own story. ${ }^{62}$ The members of Słoneczna Ekipa Tworząca, authors of Linie, also wanted to publish their periodical on tapes (first audio, and later on video cassettes). Their idea was to add to each cover a jar of jam or honey (since they could not decide which option to choose, they eventually abandoned their idea altogether ${ }^{63}$ ). Wojciech Maria Koronkiewicz used special stencils to decorate privately-published Białystok-based poetry collections which stemmed from the artzin style ${ }^{64}$. In his Biblioteka Jednego Wiersza, he published, e.g. a collection by Marcin Baran entitled Sny słodkie jak chuj "on plastic foil with a fused in fly" while the cover of the sheet with a poem by Lopez Mausere was made of crushed cardboard egg packaging ${ }^{66}$. "Koronkiewicz also uses other materials for producing his covers, e.g. metal plates" ${ }^{67}$. Finally, calligraphed poems in combination with colour graphics formed the collection by Jacek Podsiadło entitled Królowo kolorów published by Xero. ${ }^{68}$

This artistic awareness was also confirmed in the auto-parodic and bluff focus of artzin creators. They sometimes created zins which mocked artzin forms (that was the character of the Zielona Góra-based artzins published once in 1994: Podaj Mi Nuz and Krew W Wannie ${ }^{69}$; a prospect/business card of Tomasz Majeran within the framework of a series of meetings entitled Barbarzyńcy and not organised in Legnica was called: "Tymianek - jedyne pismo ze smakiem" (Thyme - the

\footnotetext{
${ }^{59}$ K. Puczko, op. cit., p. 15.

${ }^{60} \mathrm{~K}$. Varga, "Trzecia droga", p. 9.

${ }^{61}$ Ibid. Vide also R. Smoczyński, "Przyspieszyć...”, p. 15.

${ }^{62}$ K. Varga, "Trzecia droga”, p. 9.

${ }^{63}$ Słoneczna Ekipa Tworząca, op. cit., p. 20.

${ }^{64}$ P. Dunin-Wąsowicz, "Donos z czasów bez faktury", p. 56.

${ }^{65}$ P. Dunin-Wąsowicz, K. Varga, Parnas bis, p. 11. Cf. also K. Varga, “Trzecia droga”, p. 10.

${ }^{66}$ Ibid.

${ }^{67}$ Ibid.

${ }^{68}$ Ibid., p. 9.

${ }^{69}$ Cf. catalogue: Art-ziny. Zielonogórska twórczość alternatywna lat 90., [pagination missing].
} 
only tasteful magazine $)^{70}$ ). Artzins also focussed on hoax activities, e.g. the Żaden artzin published in Wałbrzych and Szczawno Zdrój included an interview with invented bands for which, as i.a. Krzysztof Varga claimed, a considerable number of readers fell ${ }^{71}$. The readers also thought there existed a poetic group called Podaj Mnie Nużcholero (Gimme the Nifeyounag) who were supposed, as was stated on the cover, to be the authors of the Podaj mi Nuz artzin. ${ }^{72}$

Artzins legitimise and promote the works of "people who possess a sense of grotesque characteristic of the young"73, and who feel the need to exorcise reality with laughter. ${ }^{74}$ The projects they undertake are surely founded on "a common sense of humour." ${ }^{.75}$ However, what counts in their case is mainly the conscious act of creation - the selection of a specific presentation technique and strategy is autonomous and appears to be an act of artistic freedom in line with the principle: "you don't have to do something, you can do anything." In other words, there is no need to respect the principles of cultural or technical obligation to perform art according to some established cultural norms. ${ }^{76}$ Even if anyone can, not everyone wants to be a creator of such a magazine (that is a result of a set of mental capabilities, i.e. predilections for seeking exactly that type of manifestation and the need to choose exactly that type of expression and consistency in fulfilling one's goals - Hanna Nawrocka, co-creator of the Poznań-based Szokiren Szikzal artzin published in 19911996, one of the few women engaged in artzin movements, declared that "even if no one bought the magazine, she would still make it" ${ }^{\prime 77}$ ). At the same time, it is worth mentioning that the act of creating those often single-person magazines can be considered as an act of artistic creation, though treated with a campy pinch of salt. ${ }^{78}$ The creators of artzins were mindful about the author's image, thus they often used sophisticated noms de plume, e.g. Sławomir Burszewski, co-editor of Częstochowa -based artzins: Fenctil, Nootropil, Exkluziv, and Bachor, was credited as Almanzor, Ruben Amfiteatr, Obrazek, or Fredi Aldi; Marcin Paruzel, the co-creator of Częstochowa-based artzins: Masło Roślinne, Nootropil, and Exkluziv, was known as Cienki J., Karenina Anna, Ptak M., or Woźniak Andrzej; Jacek Podsiadło signed his works as Jac Po; Jacek Budziński, of the Lublin-based artzin Der Schwan, was

${ }^{70}$ P. Dunin-Wąsowicz, K. Varga, Parnas bis, p. 11.

${ }^{71}$ K. Varga, "Trzecia droga", p. 6. Cf. also Xerofeeria 2.0, p. 223.

${ }^{72}$ Art-ziny. Zielonogórska twórczość alternatywna lat 90., [pagination missing].

${ }^{73}$ P. Dunin-Wąsowicz, "Donos z czasów bez faktury", p. 57.

${ }^{74}$ P. Czapliński, P. Śliwiński, op. cit., p. 172.

${ }^{75}$ P. Dunin-Wąsowicz, "Donos z czasów bez faktury", p. 57.

${ }^{76}$ Cf. K. Varga, "Trzecia droga", p. 10.

${ }^{77}$ R. Smoczyński, "Przyspieszyć...”, p. 14.

${ }^{78} \mathrm{Camp}$ as an aesthetic approach, the proponents of which enjoy the piling on of kitsch and, at the same time, present an ironic disposition towards their own taste, was first described by S. Sontag in a text entitled "Notes on Camp" published in Partisan Review in 1964 - Polish translation: S. Sontag, "Notatki o kampie", trans. W. Wartenstein, Literatura na Świecie, 1979, issue 9, pp. 307-323; reprinted in: Kamp. Antologia przekładów, P. Czapliński, A. Mizerka (eds.), Universitas, Krakow 2012, pp. 49-67. 
known as Budzik or Vermin Horset; and finally, in the Zielona Góra artzin community, there operated Katos (Jacek Katarzyński), and Ziggy Stardust (aka Andrzej Tokarski) $^{79}$. Additionally, even if it was not the intention of the authors, artzins mainly create a campy pre-aesthetisation effect.

Therefore, out of all the reasons indicated, the most tempting and promising seems the perspective of placing the artzin phenomenon within the area of artistic phenomena and its functionalisation within the historical view. In other words, the search for its proper place in the history of literature and the history of art. In that sense, a publication discussing the domestic reception of one of the leading currents of avant-garde art, i.e. tracing the Dadaistic stimulus in the Polish artistic space of the 20th c., offers an excellent opportunity and the right forum for that.

\section{Dadaistic relations}

The relationships between artzins and avant-garde (including or especially Dadaistic) idioms and strategies have often been indicated during attempts at providing a holistic view of the phenomenon, which was reflected in, e.g. encyclopaedia entries: Mirosław Pęczak in Mały stownik subkultur młodzieżowych emphasised the alignment of the aesthetics of artzins with futurism and surrealism and most of all Dada ${ }^{80}$; Paweł Dunin-Wąsowicz and Krzysztof Vaga in Parnas bis wrote that "The texts published in art zins usually remained under the influence of surrealism, futurism, and Dada"81; Tomasz Stępień in Szkolny słownik wiedzy o literaturze indicated that "the literary and quasi-literary texts (poems, stories, manifestos)" published in third circulation bulletins "are often inspired by Dada, futurism, and surrealism"82; also the PWN Encyclopaedia defined an artzin as a periodical "devoted to alternative artistic literary output of the young, close in terms of its traditions to Dada, futurism, and avant-garde" 83 , which is supported by a comment by Marek Jędrzejewski according to whom "Editors of artzins usually include students fascinated with various art movements with a dominance of surrealist, futurist, and Dada motifs" ${ }^{84}$; somewhat contrary to that, Michael Fleischer, a German slavist and the author of the only book attempting to study the essence

${ }^{79}$ All the facts I included were based on personal entries in a dictionary: P. Dunin-Wąsowicz, K. Varga, Parnas bis, pp. 26-27, 149, 155, 177, 183, 186.

${ }^{80}$ Vide entry “Art-zin”, [in:] M. Pęczak, Maty słownik..., p. 10.

${ }^{81}$ Entry “Art zine”, [in:] P. Dunin-Wąsowicz, K. Varga, Parnas bis, p. 4.

${ }^{82}$ Vide T. Stępień, op. cit., p. 20.

${ }^{83}$ Entry "Fanziny", [in:] Encyklopedia PWN [online], http://encyklopedia.pwn.pl/haslo/fanziny;4658196.html [accessed on: 10.12.2015]. Significantly, the definition also exists as a cross-reference in the entry "Dada" - vide http://encyklopedia.pwn.pl/encyklopedia/dadaizm.html [accessed on: 10.12.2015].

${ }^{84}$ M. Jędrzejewski, op. cit., p. 218. Cf. also ibid., p. 219, 221. 
of artistic zins, concluded that what is striking in them is their intended lack of reference to any literary traditions - apart from the overt patronage of Dada and, to some extent, futurism, with which the creators easily identified themselves ${ }^{85}$; furthermore, Jacek Ladorucki, a library and press scientist, stressed: "Together with graffiti and happenings, zins constituted an authentic open platform giving voice to a new independent culture [...]. The aesthetics visible in Polish (but not only) artzins have a surrealist, futurist, or even sometimes Dada provenance [...]. That is embodied in the collages, primitive drawings, and cut and paste pictures published in the periodicals, which were sometimes used to create the titles." According to Piotr Rypson, the aesthetics of fanzins (one could add artzins as well) "constitute a result of a merger of the collage technique, Dada-punk typography, and short texts and announcements." ${ }^{\text {" }} 7$ pypson also stated that "The best reaction to the complacency of the new bourgeoisie, the political and religious flashiness, is to use irony and laughter, absurd, grotesque, and pastiche of other people's speech - those proven patterns taken from the poetics of Dada, surrealism, Polish futurism, and Witkacy's output." ${ }^{88}$ Researchers of the phenomenon stressed independently of each other exactly those conditions of the artzin style regardless of how they assessed it. For example, Dariusz Nowacki wrote that "the works in artzin circles and the associated studies... [are] — various neo-Dada -futurist poor imitations." 89 Therefore, even negative diagnoses did not eliminate the need for, and the capability of, the historical functioning of the phenomenon, while the placement of zin productions in a broader context inevitably results in indicating the avant-garde patronage with a preferential place for Dada. That prominent place is somewhat emphasised by the naming strategies with which artzins are often associated. They are defined as: "anti-newspapers" "anti-periodicals" "anti-magazines", ${ }^{22}$ or "counter-aesthetics" ${ }^{93}$. Even the titles of artzins use the prefix "counter" or "anti" ("kontr" and "anty" in Polish respectively) (e.g. "Rewia

${ }^{85}$ Vide M. Fleischer, Overground. Die Literatur der polnischen alternativen Subkulturen der 80er und 90er Jahre (Eine Einsicht), Verlag Otto Sagner, Munich 1994; a fragment translated into Polish: M. Fleischer, "Overground. Cechy charakterystyczne - tendencje - prądy", trans. M. J. Jaworowski, [in:] Xerofeeria 2.0., pp. 18-19 (on the approving attitude of the authors of artzins towards Dada, vide p. 19). It is not a singular voice - cf., e.g. T. Stępień, op. cit., p. 20: "Artistic avant-garde traditions are the only literary traditions to which texts in artzins refer while the authors who publish there by default ignore the previous output and any ideological or aesthetic disputes in Polish literature."

${ }^{86}$ J. Ladorucki, op. cit., pp. 50-51.

${ }^{87}$ P. Rypson, Dość Podporzadku!, p. 10.

${ }^{88}$ Ibid.

${ }^{89}$ D. Nowacki, Zawód: czytelnik, Znak, Krakow 1999, p. 33.

${ }^{90}$ Entry "Fanzin", [in:] M. Pęczak, Mały stownik..., p. 24.

${ }^{91}$ K. Varga, "Trzecia droga”, p. 15; J. Bińczycki, Ziny..., p. 68.

${ }^{92}$ Vide K. Varga, "Trzecia droga”, p. 9 (etc.)

${ }^{93}$ Entry "Fanzin”, [in:] M. Pęczak, Mały stownik..., p. 24. 
Kontrsztuki", "Anty Zine"...), which can be easily compared to the history of the prefix "anti" in discussions of Dada strategies, which were often grouped as anti-art. Apparently, Dada connections do not necessarily have to be articulated directly to amplify the meaning. ${ }^{94}$ Moreover, they become evident not only when attempting a global view in the nature of the counter-cultural bulletin output, but also when discussing the tactics, techniques, and contents of specific bulletins or artistic projects of the representatives of the artzin community in general - e.g. Krzysztof Varga interpreted as a Duchamp gesture the idea of Jan Sobczak to include in Tytuł confessions of a schizophrenic woman recorded by him (unless that was a deception, something that is very common in artzins), and a rewritten speech by Mao Zedong (the author of the zin was supposedly driven by a desire to depict an idea that "there are things which can be art depending on the context - vide Marcel Duchamp's urinal-turn-fountain.)" ${ }^{955}$ Mirosław Pęczak stated that “《Higiena», similarly to other art-zins («Linie», «Lampa», «Litera») remains under the influence of neo-Dada. ${ }^{" 96}$ The Parnas bis dictionary stated that Dada was endorsed by Żaden artzin published in Wałbrzych and Szczawno Zdrój ${ }^{97}$ while Tygodnik Leeeżeć (a part of the Łódź-based Wspólnota Leeeżeć happening collective) "Published, e.g. Dadaistic poems by Upławy Nonsensu"98; "neo-Dadaistic absurd texts" (including, e.g. poems by the Upławy Nonsensu collective) were also published by another Łódź-based artzin called Kau Gryzoni Na Serze ${ }^{99}$; the same source stated about the publisher of the Częstochowa-based artzins Fenactil, Nootropil, and Ekskluziv: "As a poet, Burszewski [...] refers to futurism and Dada"100; Ziggy Stardust was presented as a "neo-Dadaist"101, while Paweł Konnak as a "Co-creator and chronicler of Totart, the publisher of fanzins: "Gangrena» and «Futurfoto» (early 1980s), technical editor of Księgozbiór Zlew Polski, editor of various catalogues and other Totart publications, including «Metafizyka Społeczn»", who himself "created typical Dadaistic-banalistic Totart poems." 102

${ }^{94}$ In fact, sometimes when interpreting third circulation periodicals, commentators refer through analogy to the techniques rooted in avant-garde strategies in a way which might also suggest a need to reactivate a certain heritage - cf., e.g. the following remark regarding, i.a. the aesthetics and typographic shape of zins: "One reaction to the experience of information noise may be to feature in a proper manner that exact noise. A paradoxical pattern of a communicative act would be a radical reaction where «nothing» communicates «nothing», chaos and absurd are treated as ready mades" (M. Pęczak, “Alternatywne komunikowanie", p. 214).

${ }^{95}$ K. Varga, "Trzecia droga”, p. 9.

${ }^{96}$ Entry “Art-zin”, [in:] M. Pęczak, Maty stownik..., p. 10.

${ }^{97}$ Entry “Żaden”, [in:] P. Dunin-Wąsowicz, K. Varga, Parnas bis, p. 237.

${ }^{98}$ Entry “Tygodnik Leeeżeć”, [in:] P. Dunin-Wąsowicz, K. Varga, Parnas bis, p. 214.

${ }^{99}$ Entry "Kau Gryzoni Na Serze”, [in:] P. Dunin-Wąsowicz, K. Varga, Parnas bis, p. 84.

${ }^{100}$ Entry "Burszewski Sławomir", [in:] P. Dunin-Wąsowicz, K. Varga, Parnas bis, p. 27.

${ }^{101}$ Entry "Stardust Ziggy”, [in:] P. Dunin-Wąsowicz, K. Varga, Parnas bis, p. 186.

${ }^{102}$ Entry "Konnak Paweł”, [in:] P. Dunin-Wąsowicz, K. Varga, Parnas bis, pp. 96-97. Cf. also P. Koñjo Konnak, Dzieła zebrane i wylane, CKW, Gdańsk 2009. 
A detailed analysis of the Zielona Góra literary zins also results in a clear diagnosis: "The published texts - poetry, prose, and manifestos - usually written in the form of absurd humoresque stories, pastiche, and parody, were created under the clear influence of Dada, surrealism, and futurism, to which the creators openly admitted." ${ }^{103}$ The discussions of artzin(-related) output include very many such indications which function as apparent and convenient mental shortcuts. On the one hand, one can see that the Dadaistic and avant-garde associations come to commentators in an obvious way, on the other, they treat such assignments as indisputable and comprehensible identifiers completely adequate to the object of their description. That compatibility is justified and amplified in the light of declarations and overt announcements included in specific zins or statements by their authors. For example, in the second issue of Litera published in Krakow by Ex Pert (Dariusz Eckert), there appeared graphic variations which referred to the word "Dada" with a caption (or incorporated heading): Kurt Schwitters. Then, the previously-mentioned Sławomir Almanzor Burszewski was the author of $\mathrm{Ma}$ nifest $n$ r 1. Smrut w butonerce dated "7.04.1991" and first published in Exkluziv. $N B$, commentators indicated that the representatives of the artzin community had a strong inclination towards creating "programme manifestos (more or less serious) referring to the traditions of futurism, Dada, and surrealism"104:

We shall draw inspiration from interwar movements, i.e. surrealism, Dada, and futurism. (but let us not forget we live 70 years later). We wish to create a fresh atmosphere of the new times, restore the denture of our awareness. Our minds must take a rest from the mundane Polish reality, and prepare for immediate Europeanisation; and it must be added that DADA is a super-national language.

$[\ldots]$

We need absurd, nonsense, vulgarity, perversion, and ugliness. And we have exactly that to offer. Enough with the positivism of the society, communism, religion, romanticism, Solidarity! Enough with over-intellectuality, pretentiousness, philosophy for philosophy's sake! May EMOTIONS, INSTINCTS, THE PRIMITIVE, and the frenzy of young brains resound. Let us jump from sky scrapers, let us say to everyone: "ADIEU!".

Vivat Breton! Schwitters! Jasieński! Chlebnikow! Tzara!!!

LIVE LONG!! ${ }^{105}$

${ }^{103}$ A. Kamińska, “Art-ziny...,", p. 142.

${ }^{104}$ P. Dunin-Wąsowicz, "Jak zakwitly...”, p. 52.

${ }^{105}$ S. Burszewski, "Manifest nr 1. Smrut w butońerce", Fenactil 1991, issue 4. The significance of that statement, which constituted a model embodiment of the explicite proposed artistic programme of artzin creators, was proven by its many reprints - vide Fenactil, Nootropil, Exkluziv 1991-1994 [reprint from photocopies of Fenactil, Nootropil, Exkluziv from the collection of Pawer Dunin-Wąsowicz], Lampa i Iskra Boża, Warsaw 2005, p. 45; Xerofeeria 2.0, p. 79; S. Burszewski, Rymarstwo. Poezje ekskluzywne, Lampa i Iskra Boża, Warsaw 1996, p. 64 (I quote as per the reference in that issue). The text is also quoted in extenso, e.g. K. Varga, "Trzecia droga", p. 13 and T. Stępien, op. cit., p. 20. 
The quoted manifesto confirmed that the creators of artzins displayed at least some rudimentary knowledge of 20th-century artistic phenomena, i.e. they were not just amateurs, or literary Nikifors (thus, the statement on their amateur activities would be unfounded ${ }^{106}$ ). In fact, there was proof of their obvious fascination with specific artistic proposals, among which Dada occupied a prominent position, e.g. Paweł Koñjo Konnak, a Totart activist, recalled his readings of books discussing avant-garde phenomena in art: "the out-fucking-standing opus entitled Dadaizm by Hans Richter. The intense lines of that crazy bible of transgressions and chaos proved emphatically that the lunatics of every epoch had problems when faced with the domination of the normals." 107 Interestingly enough, Koñjo Konnak was apparently most moved by the "fate of such Dadaistic bulletins as Die Rosa Brille, Die Pleitte, Der Gegner, Die Pille, which were published as two or three issues only to step down from the stage subject to seizure, and a ban on printing. It reminded him of his own struggles to remain above the surface with each new volume of Totart" ${ }^{108}$. Similar statements displayed an underlying conviction that it was worth toying with art even if one knew from the start to what effects (or lack of such) it led. A fitting conclusion on artistic practices in the area of the plastic arts was made in the 1990s by Grzegorz Dziamski: "A phenomenon is being born which could be referred to as «the time of re-discovery». It does not matter that someone else made those discoveries before them; what is important is that they are the ones who are discovering, reaching them on their own." 109 Thus, the do it yourself directive, so highly esteemed by the creator of artzins, would receive a specific instruction: do it

${ }^{106}$ Also in the light of blusterous statements like: "We do not accept Duchamp the riddler, who was more focussed on the philosophy of art than art itself" (KCN, "Manifest 9/87 pop.", Chura. As cited in: Xerofeeria 2.0, p. 37.

${ }^{107}$ As cited in: M. Chmiel, Paweł Koñjo Konnak - fenomen uczestnictwa kulturze współczesnej, Narodowe Centrum Kultury, Warsaw 2013, p. 32. It is also worth noting that P. Koñjo Konnak is not the only contemporary creator who approached H. Richter's book with high esteem and admiration. Darek Foks spoke of its form-making power when he promoted his novel Kebab Meister during a meeting at the Wrocław Tajne Komplety bookstore and café. The writer was not actually related to the artzin movement, but he displayed a tendency for writing in such a way which could feed such bulletin productions (vide a recorded fragment of an interview: Darek Foks w Tajnych Kompletach: "Kebab Meister", https://www.youtube.com/watch?v=M3KRTduqf1o, 7'02" [accessed on: 10.12.2015]). It is important that creators who are active today in the field of literature highlight such an inclination in their reading.

${ }^{108}$ Ibid. It would be a good idea to study the synchronicity between the assumptions, aesthetics and typographic solutions present in motor organs and the more or less ephemeral prints accompanying avant-garde performances (by Dadaists and futurists in particular). A synthetic review of Dadaistic writings edited by P. Kurc-Maj was presented in the catalogue: Dada Impuls/e. Kolekcja Egidio Marzony / Egidio Marzona Collection, P. Kurc-Maj, P. Polit (eds.), Muzeum Sztuki w Łodzi, 2015, pp. 92-103. Vide also H. Richter, Dadaizm. Sztuka i antysztuka, trans. J. St. Buras, Wydawnictwa Artystyczne i Filmowe, Warsaw 1983.

${ }^{109}$ G. Dziamski, "Przyszłość sztuki i estetyczna anestezja”, [in:] Kultura i sztuka u progu XXI wieku, S. Krzemień-Ojak (ed.), Trans Humana, Białystok 1997, p. 263. 
on your own, from scratch, once more but this time in your own style and see not only how to use a specific effect, but also how to reach it "70 years later."

Many authors of artzins emphasised the impression that the discovery of Dadaistic practices had on them, and they indicated the resilience and relevance of Dadaistic (and avant-garde) traditions for them (even if they treated it, like everything else, in a mocking style), which they firmly expressed in literary works, e.g. Sławomir Burszewski wrote a poem entitled Dada żyje (Dada Lives), which most probably referred to a Zielona Góra-based artzin called Dada rzyje. Jacek Katos Katarzyński, its publisher, is another programme-definer and probably the most consistent continuator in the alternative literary community of Dada principles, a specialist in "Dadaistic trips" 110 , author of various references to the patronage in his own poetic and publishing operations - his works included a 1997 collection of poems entitled Dada rzyje, czyli co było jest i wcale nie musi być dada, and he added to his artzin entitled Dada rzyje, e.g. a supplement entitled Dada rzygi (Dada Puke). At this point it is worth noting that the Dadaistic patronage is evident in artzin naming policy, e.g.: Cabaret Nonsens, Chura, Czyżby Agonia Uczuć, Kau Gryzoni Na Serze; Jest Już Jutro; Tygodnik Leeeżeć, Tytuł Dzien Do Blyy, Fenactil, Nootropil, Exkluziv, Schistosoma, Moja Szajba, Szokiren Szikzal, Conieco, Dolina Lalek, Biegunka, Blamaż, Bohomazin, Brains Curiosity, Brytan Od Nowa, Driakiew, Onomost, Dziąło, Don Alejo, Drut, Dobry Jaśko, Egoistyczna Butelka, Gównoprawda, Haber Haberabis, Haha Kurier Świecacy, Mamusiu, Masło Roślinne, Non Conform, Ojo De Dios, Podaj Mi Nóż, Pót-Nocnik, Silenzio e Parole, Shuflada, Synteza, Payton, Vae Victis, Grzebień Do Traw, Róbta Co Chceta, Teatr Pk, Trujaca Fala, Watroba, Wyborny Trup, Czas Na Porzeczki, Anty Zine, Barbarzyńca W Katedrze, De Lirnik, Die Hulle, God Is Black - Yes, She Is! Szajba, Krew W Wannie, Gorycz, Kotnierz Wolności, Lampa i Iskra Boża, Mata Ulicznica, Masz Medium, Patia, Poniżej, Rewia Kontrsztuki, Der Schwan, Skafander Striptiz, Szinear, Świnia, Xerro, Xuxem, Żulio Cezaro ${ }^{111}$.

Compositions which feature phonetic games and experiments with the linguistic matter, published in artzins or third circulation publications, also related to Dada poetics, e.g.:

Jacek Katos Katarzyński

ZGRUDEWISZCZE BADGASZCZE

ISTIOŁDI RODE GANDA

ISTOŁDI RODE WANDE

BADGLUSZCZI PADS WLANE

ER TIUDI ZAMISKANE

${ }^{110}$ Vide report: R. Smoczyński, "Przyspieszyć...”, p. 14.

${ }^{111}$ A summary of those and other titles is included in the entry "Art zine", [in:] P. Dunin-Wąsowicz, K. Varga, Parnas bis, p. 5. I also used the details included in the anthology Xerofeeria 2.0. 
WANDO ZGRES ZATIOŁDI

WANDO ZOSO GOŁDI

I GRANE BADS BADS ZANE

I GRANE BADS OLSZANE

A ZGRASZCZO BUDU RONDE

A ZGRASZCZO WAR SUKONDE

I WASZCZI PALD MAZDANE

EL TIUDI ZAMISKANE

\author{
A SZCZLODE GIUZO ŁADIN \\ WARSIN DE WASTI GRADIN \\ EL NIUSZCZI MAZGASZCZE \\ ZGRUDEWISZCZE MAGASZCZE ${ }^{112}$
}

Thompson

SHORT STORY

IN RESPONSE TO A LETTER

Pan Bóczek z Buczacza

nabzdyczył brew

i wychynła z ponad

pa pa pa

da da da ${ }^{113}$

Jan Sobczak

KWADRAT DOBROCI

dobry

obryd

br do

rydob

ydobr

a dziurka jest

dla wtajemniczonych ${ }^{114}$

${ }^{112}$ J. Katos Katarzyński, “Zgrudewiszcze Badgaszcze”, Dada Rzyje, 1988, issue 1. As cited in: Xerofeeria 2.0, p. 49. The text was also cited in (without the capitalisation from the original wording) K. Varga, "Trzecia droga”, p. 17.

${ }^{113}$ Thompson, "Krótka historia w odpowiedzi na list", Dada Rzyje, 1992, issue 12. As cited in: Xerofeeria 2.0, p. 53.

${ }^{114}$ As cited in: J. Sobczak, "Kwadrat dobroci”, [in:] Macie swoich poetów. Liryka polska urodzona po 1960 r. Wypisy, selection and editing: P. Dunin-Wąsowicz, J. Klejnocki, K. Varga, 3rd edition amended, Lampa i Iskra Boża, Warsaw 1997, p. 169. The poem was also printed in the anthology Xerofrenia. 
Rafał Czupryniak

\section{SMUTNA WATANAHA}

Węsząc wężydłem, złotobrzeźnie tupiąc,
Sapał satanicznym skowytem blaszasa
źdźbłem chędożąc lokoko celibacąc
Magogo bazaru wyłupując dedi dada
Wtryskując pryszcz w siepacza siemasz
Stawadida dudni klepiąc nudności
Glamdając rukukaka stawając dęba
Posłusznie topiszczem kiwając na boki
Patosem karminowo skulonym na pysk
Skubowanym bękopławem rzygając oczyma
Dłubiąc dłuboszczakiem symfonią miskokisk
Wycina widłorybę strugają siną tablete baru-baru
Drapiąc gardło przestrzeto sokowirując
Machetołaciato wstrzępośnym dumidłem
Glamając glansują pupakę pumkając
Puszystym sromem o strych wypastutrzepuję

Furthermore, the Dadaistic pedigree is easily assignable to the general presentation technique in artzins - in such categories one could discuss their montage-collage incoherence as well as the use of appropriation strategies (in the area of linguistic and plastic organisation). Dadaistic gestures can also be found at the level of the often used provocative actions of happening nature, e.g. Jan Sobczak sent to Razem a package in which he placed cut outs from the magazine between slices of cheese (from his section "Osobno", to be precise) of nude photographs of women (in the PRL, Razem was probably the only or one of the few magazines publishing photographs of nude models) $)^{116}$; Andrzej Tokarski aka Ziggy Stardust, who was very active in the Zielona Gorra alternative community, was known for his swashbuckling and mocking performances aimed at interactive confrontations. ${ }^{117}$

It is clearly visible that the relationship of artzins (or broadly: counter-cultural projects ${ }^{118}$ ) with Dada was manifested in various areas. In such a precise reconstruction, one could consider various determiners: the declarative layer, naming practices, the publishing side, the global aesthetic undertone, the technical layer, and the formal or even typographic layers. The bridge between the blusterous and anarchistic avant-garde trend was also built by the worldview alignment and

${ }^{115}$ R. Czupryniak, "SMUTNA WATANAHA", Mamusiu 1990 [issue as cited in: Xerofeeria 2.0, p. 137.

${ }^{116}$ I quoted the information after: K. Varga, "Trzecia droga”, p. 9.

${ }^{117}$ Vide R. Smoczyński, “Przyspieszyć...”, p. 19.

${ }^{118}$ R. Tekieli referred to, e.g. a phenomenon of the theatre "Dada tractor", though he did not discuss it in detail (vide R. Tekieli, "Fuckty (1)", p. 160). It could be an interesting reference to the Dadaistic (quasi-)theatre activities - more on the subject, vide H. Béhar, Dada i surrealizm w teatrze, trans. P. Szymanowski, Wydawnictwa Artystyczne i Filmowe, Warsaw 1975. 
the generational determiner (in the sense of: the domain of youth). The similarity between the principles of approaching the findings on Dada and the Polish artistic counter-culture of the 1980 s and 90 s seems evident. In both cases, they were governed by storytelling, i.e. the writing of the history of Dada and of contestation movements of the 1980s and the early-1990s was often done through forcing particular facts and events into the framework of a subjective and privatised story. Their episodic nature and the anecdote clearly downgraded any attempts at developing a comprehensive and remote view of the phenomenon while anthologisation and cataloguing prevailed over monographisation. One could assume that such artistic proposals have had something which distinctly favours the initiation of exactly such an approach as the most accurate method or even intuitively chosen path for coping with similar phenomena.

However, the most significant bridge between the literary output of the Polish counter-culture of the 1980s and 90s, and Dada established the intrinsically understood strategical and programme directives which were carried by the authors of artzins in their general motivations to create magazines used for no-one-knows-what ${ }^{119}$ and published "for nothing" ${ }^{20}$; in the drive to do NOTHING instead of something, damage literature and art as much as possible, consistently lowering the artistic level, deconstruct, trivialise, and deprive any form of art of its grounds, wonder and test what else can be ridiculed or questioned, seek even more elaborate and unexpected reasons for unwavering and incessant hamming it up, and to act without (self-)censorship, avoiding any compromise with the institutional, customary, social and artistic norms. ${ }^{121}$

Dadaistic gestures of freedom manifested within the artistic realm (artzins were, as Przemysław Czapliński put it, "a training camp in independence from the obligation of writing well, a proposal for a new imagination distancing oneself from the mass culture"122) also assumed a somewhat political meaning - when Paweł Dunin-Wąsowicz asked the members of Słoneczna Ekipa Tworząca and the publishers of Linie: "Did you fight communism?" they responded: "No... [...]

${ }^{119}$ I borrowed the term from D. Grabowski, op. cit., who used it to define A. Warhol's "Interview" magazine.

${ }^{120}$ That was the principle and slogan of Totart creators (TOTART FOR NOTHING), which was discussed by Z. Sajnór, the movement's leader, in an introduction to "Metafizyka Społeczna" - vide, e.g. P. Koñjo Konnak, Gangrena. Mój punk rock song, Narodowe Centrum Kultury, Warsaw 2011, p. 377.

${ }^{121}$ The notion of self-censorship within Dada was analysed by I. Grigorescu, "Freud i ruch Dada", [in:] Dada East? Rumuńskie konteksty dadaizmu / Dad East? Romanian Context of Dadaism [exhibition catalogue], Z. Machnicka (ed.), Zachęta Narodowa Galeria Sztuki, Warsaw 2008, pp. 66-70.

${ }^{122}$ P. Czapliński, P. Śliwiński, "Pomarańczowa alternatywa literatury polskiej? O Lampie i Iskrze Bożej”, [in:] P. Czapliński, P. Śliwiński, Kontrapunkt. Rozmowy o ksiązkach, Obserwator, Poznań 1999, p. 94. 
Communism fought us." ${ }^{23}$ A similar statement was offered by Paweł Jarodzki: "we realised that you shouldn't fight for freedom - you need to use it." 124 The main sign of the anti-system disposition (in the artistic and political sense) of the creators of artzins was the independence, the ability to dismantle any absurdity of the reality through their sense of humour and a smile as well as unpredictability ("They wrote in such a way to drive everyone around crazy." 125 )

\section{Cognitive benefits}

There are various cognitive benefits from studying artzins in detail. Their role as generators of literary senses typical for the 1990s was often emphasised, particularly a strategy referred to as banalism. ${ }^{126}$ But artzins can also be viewed not only in the categories of "a laboratory of new literature" 127 , a vanguard, and sign of what was to come and what wanted to be fulfilled. It seems also justified to seek in those proposals an opportunity to organise the past.

I believe it is important to ask what changes, or becomes clearer, (but also: what becomes consolidated and preserved) upon considering artzins as rightful components of literary traditions. Such an approach offers an opportunity to create alternative narrations combining 20th-century literary and artistic phenomena for various reasons left on the outskirts of literary science discourse (the point here is not to conduct a significant re-evaluation or some dramatic shift, but to create a perspective, and a capacious and adequate formula merging not as much the marginalised phenomena, but mainly those in relation to which we are often scientifically helpless or for which we are still seeking adequate contexts - those include, e.g. the collages made in the 1960 s by Wisława Szymborska ${ }^{128}$, the

${ }^{123}$ Słoneczna Ekipa Tworząca, op. cit., p. 15.

124 "Autocenzura: co jest, a co nie jest Luxusem?" [interview with the Luxus collective], interview by P. Rypson, [in:] A. Mituś, P. Stasiowski, P. Rypson, op. cit., p. 175. Cf. also P. Koñjo Konnak, "Intro. P. Koñjo Konnak - zabawa wyższej użyteczności o dość poważnych konsekwencjach", [in:] Dzieła zebrane i wylane, CKW, Gdańsk 2009, p. 15: "we prefer to always be free, even in the most Gulag of times of the final end."

${ }^{125}$ Vide "Nowa epoka w stanie pierwiastkowym. Rozmowa z Wojciechem Kajtochem", op. cit., p. 71. Unpredictability as a virtue and an advantage of the Lampa i Iskra Boża publishing house and others like it was stressed by P. Śliwiński - P. Czapliński, P. Śliwiński, "Pomarańczowa alternatywa...", p. 94.

${ }^{126}$ Vide M. Fleischer, Overground. Cechy charakterystyczne..., pp. 18-19; M. Lachman, Gry $z$, tandeta” w prozie polskiej po 1989 roku, Universitas, Krakow 2004, pp. 290-308, P. Dunin-Wąsowicz, "Jak zakwitły...”, pp. 53-54; "Nowa epoka w stanie pierwiastkowym. Rozmowa z Wojciechem Kajtochem", pp. 71-76.

${ }^{127}$ Ibid., p. 71.

${ }^{128}$ Vide W. Szymborska, Kolaże / Collages, MOCAK, Krakow 2014. 
collage-poems entitled $G$ by Ryszard Krynicki published in $1971^{129}$, Nikiformy (1982) by Edward Redliński, but maybe it could also open an interesting perspective for Witkacy's "Papierek Lakmusowy", for the comedic in nature one-day futuristic bulletins from the community of Katarynka Warszawska and the like, and for various scandalous and blusterous instances of young literary magazines of the type of Lucifer ${ }^{130} \ldots$ Significantly enough, any attempt at seeking such adequate merging formulas and creating new orders and narrative lines for the literature of the 20th c. results in the transformation of the shape of Dada, the foundation of many literary practices.

In my opinion, the major significance of artzins lies in viewing them as preservers or verifiers of theses on Dada. In other words, for me, the most interesting question is how the direction of reception influences the perception of the source. In the light of a neo-Dada artzin adventure, the conviction about the episodic and non-productive nature of Dada in Polish literature, about its scanty heritage, closed area of influence, or even the convenient yet mechanical "I KNOW DADA" limitation to the 1980s does not hold. Dada seems not so much a fully discovered and unprocessed tradition in Poland (perhaps it would also be a good idea to emphasise and study in this context the paradox of the question: "How Dada could not have been present in Poland if it had presented itself?")

At the same time, other even more important issues come to mind regarding the global perception of Dada. Its artzin reception reveals that the question it tried to answer was not how to become art but how to successfully operate within culture using artistic means (also: how to operate in one's original style, how to take matters into one's own hands). That consolidates the perception of Dada as the holder and the inventor of the strategy for appropriating, treated as a convenient artistic technique, which paradoxically can constitute in some contexts a statement of the freedom of creation and an antidote to cultural appropriation. The contemporary reception of Dada also reveals the fact that it is valid to consider it not necessarily in the destructive-nihilist dimension, but rather one which tests the culture's framework; it seems not a smasher of order (or its remains) but a good indicator of the sources of all types of disorder. Additionally, one can also place in focus its therapeutic dimension (in the sense of the need to let off steam upon realising in a given moment the oppressiveness of culture).

Evidently, Dada was, out of all the 20th-century artistic movements, the best at communicating not only particular forms and techniques for easy acquisition and reclaiming, but also for transmitting the model of particular experiences. Thus, any reference to it is a reference not only to the style and aesthetics formed

${ }^{129}$ Vide new edition of the same collection: R. Krynicki, G, January 1971/2014, MOCAK, Krakow 2014.

${ }^{130}$ Vide entry "Lucifer", [in:] Leksykon Lublin [on-line], http://teatrnn.pl/leksykon/node/2735/ \%E2\%80\%9Elucifer\%E2\%80\%9D_1921_1922 [accessed on: 10.12.2015]. 
within its focus, but mainly to the foundations and the still current models of cultural experience. Dada in the light of its artzin reception seems not as much an artistic or intellectual but rather an emotional need: it is a proposal with which one cannot and will not grow up, but, at the same time, it is an idiom, a module, a strategy, and a basis useful when, by default, we do not want to, we cannot, or we do not have the opportunity to age.

Shortened version of this article was published in Polish:

Magdalena Lachman, Artzinowe (re)aktywacje dadaizmu, [in:] Impuls dadaistyczny w polskiej sztuce i literaturze dwudziestowiecznej, ed. Paulina Kurc-Maj, Pawel Polit, Muzeum Sztuki w Lodzi, Łódź 2017, pp. 348-370.

\section{Bibliography}

Antologia zinów 1989-2001, D. Ciosmak (ed.), R. Grodzicki et al. (do-editors), Wydawnictwo Liberation, Kielce 2001.

Art Zine Gallery [catalogue of the 1st Art Zine Gallery festival], Zielona Góra 1992.

Art-ziny. Zielonogórska twórczość alternatywna lat 90. [exhibition catalogue: Muzeum Ziemi Lubuskiej w Zielonej Górze, IX-X 2009, exhibition concept and program, catalogue content: A. Kamińska, consultants: J. Katos Katarzyński, B. A. Kieć] Muzeum Ziemi Lubuskiej, Zielona Góra 2009.

Bielska K., "Trzeci obieg wydawniczy w PRL oraz drugi obieg w latach 70. i 80.", Pedagogia Ojcostwa, 2013, issue 1, p. 194-201 (available on-line: http://www.pedkat.pl/images/czasopisma/ po6/po614.pdf 2015.12.]).

Bińczycki J., “Ziny. Najkrótsze wprowadzenie”, Ha!art, 2011, issue 35/36, pp. 67-68.

Burnetko K., "III obieg - wciąż bunt i niezależność", Polityka, 1992, issue 30, p. 7.

Chmiel M. Pawet Koñjo Konnak - fenomen uczestnictwa w sztuce współczesnej, Narodowe Centrum Kultury, Warsaw 2013.

Chojnacki R., "Fizjologia art zinu, czyli rozważania eklektycznego filozofa z Lampq w dłoni”, Studium, 1996, issue 2/3, pp. 166-168.

Czapliński P., Śliwiński P., "Przesilenie wrażliwości", [in:] Literatura polska 1976-1998. Przewodnik po prozie i poezji, Wydawnictwo Literackie, Krakow 1999, pp. 169-173.

Czapliński P., Śliwiński P., "Pomarańczowa alternatywa literatury polskiej? O Lampie i Iskrze Bożej”, [in:] Kontrapunkt. Rozmowy o ksią̇kach, Obserwator, Poznań 1999, pp. 91-94.

Drągowska M., Kuryłek D. Tatar E. M., "Krótka historia Grupy Ładnie”, Korporacja Ha!art, Krakow 2008.

"Drugi Warszawski Art Zine Show 20-21 maja 1994", Krzywe Koło Literatury, 1994, issue 5, pp. 6-7.

Drzewucki J., "Poezja trzeciego obiegu", Informator Kulturalny Województwa Zielonogórskiego, 1995, issue 2, p. 5.

Drzewucki J., "Poezja trzeciego obiegu. Kazik Malinowski, Ziggy Stardust i inni”, Plus Minus [suppl. to Rzeczpospolita] 1994, issue 46, p. 17.

Dunin-Wąsowicz P., "Inny obieg", Polityka, 1991, issue 47, p. 8.

Dunin-Wąsowicz P., "Jak zakwitły i zwiędły kwiaty technologii i demokracji - artziny w Polsce”, [in:] Kultura niezależna w Polsce 1989-2009, P. Marecki (ed.), Korporacja Ha!art, Krakow 2010, pp. 47-60.

Dunin-Wąsowicz P., Rozmowy Lampowe 1993-2007, Lampa i Iskra Boża, Warsaw 2007. 
Dunin-Wąsowicz P. - interview: Donos z czasów bez faktury. O artzinach, poetyce tytułów i wspólnej sieci punkrockerów - z wydawcą, redaktorem naczelnym Lampy i autorem książki Warszawa fantastyczna" - P. Dunin-Wąsowiczem interviewed by A. Wolny-Hamkało, Biuro [Press Office of BWA Wrocław] 2012 issue 1 (issue 4: Lata osiemdziesiate), pp. 54-57.

Dunin-Wąsowicz P. - interview: "Mogłem na tym tracić - rozmowa z Pawłem Dunin-Wąsowiczem o Lampie", [in:] P. Marecki, Pospolite ruszenie. Czasopisma kulturalno-literackie w Polsce po 1989 roku. Rozmowy z redaktorami, Korporacja Ha!art, Krakow 2005, pp. 65-88.

Dunin-Wąsowicz P. - interview: "Portret wydawcy z czasów dojrzałości. W osiemnastolecie istnienia Lampy i Iskry Bożej interview with P. Dunin-Wąsowicz” conducted by Emilia Kledzik, Joanna Roszak, Czas Kultury, 2009, issue 5, pp. 85-98.

Dunin-Wąsowicz P., Smoczyński R., "Zlot awangardy i ariergardy w Zielonej Górze”, Życie Warszawy, 1992, issue 239, p. 13.

Dunin-Wąsowicz P., Varga K., Parnas bis. Stownik literatury polskiej urodzonej po 1960 roku, 3rd edition, Lampa i Iskra Boża, Warsaw 1998.

Fenactil, Nootropil, Exkluziv 1991-1994 [reprint from photocopies of Fenactil, Nootropil, Exkluziv from the collection of Paweł Dunin-Wąsowicz], Lampa i Iskra Boża, Warsaw 2005.

Firlej-Buzon A., "Historia polskich fanzinów", Acta Universitatis Wratislaviensis. Bibliotekoznawstwo [vol.] 21 (1998), pp. 45-56.

Fleischer M., Overground. Die Literatur der polnischen alternativen Subkulturen der 80er und 90er Jahre (Eine Einsicht), Verlag Otto Sagner, München 1994.

Fleischer M., "Banalizm? Overground: cechy charakterystyczne - tendencje - prądy", trans. M. J. Jaworowski, [in:] Xerofuria. Antologia-katalog. III warszawski Art Zine Show, 20 maja 1995, editing, introduction and notes: P. Dunin-Wąsowicz, Staromiejski Dom Kultury, Warsaw 1995, pp. 125-128, reprint as: "Overground. Cechy charakterystyczne - tendencje - prądy", trans. M. J. Jaworowski, [in:] Xerofeeria 2.0. Antologia artzinów. Polskie alternatywne pisma literackie 1980-2000. Wersja beta, P. Dunin-Wąsowicz, Lampa i Iskra Boża, Warsaw 2002, pp. $18-19$.

Głowacki B., "Kontrkultura w Polsce - fakt czy fikcja? Lata 80. i 90. w wypowiedziach animatorów kontrkultury na łamach fanzinów", Stan Rzeczy, 2014, issue 2., pp. 95-118.

Głowacki B., "Prasa trzeciego obiegu w okresie przełomu", Kultura-Media-Teologia, 2010, issue 3, pp. 33-43.

Grabowski P., "Zrób sobie dobrze zin. Od niezależności jako idei do niezależności jako formy”, Res Publica Nowa 2011, issue 16, pp. 66-72; in an abbreviated form the text is also available on-line: P. Grabowski, “Zrób sobie dobrze zin”, Respublica, 10 III 2012 [on-line], http:// publica.pl/teksty/zrob-sobie-dobrze-zin-od-niezaleznosci-jako-idei-do-niezaleznosci-jako -formy-28350.html [accessed on: 10.12.2015].

Haczek Z., “Art-zine: głos spod ziemi”, Gazeta Lubuska, 1992, issue 238, p. 13.

Idzikowska M., “O pewnej osobliwości nazewniczej-tytuły zinów”, Filologia Polska [vol.] 3 (2007), pp. 43-59 [monographic issue: Między stowem a obrazem, K. Smużniak (ed.), Wydawnictwo Uniwersytetu Zielonogórskiego, Zielona Góra 2007].

Jesswein R., "Trzeci obieg”, Odra, 1985, issue 3, pp. 34-39.

Jędrzejewski M., Młodzież a subkultury. Problematyka edukacyjna, Wydawnictwo Akademickie „Żak”, Warsaw 1999.

Kajtoch W., “Czym jest zin?”, Ulica Wszystkich Świętych. Miesięcznik Mail Artu, 2001, issue 7, p. 4 [access on-line: http://zinelibrary.pl/index.php?option=com_content\&view=article\&id=118: wojciech-kajtoch-czym-jest-zin\&catid=11:o-zinach\&Itemid=3]

Kajtoch W., Świat prasy alternatywnej w zwierciadle jej słownictwa, Wydawnictwo Uniwersytetu Jagiellońskiego, Krakow 1999. 
Kamińska A., “Art-ziny. Zielonogórska twórczość alternatywna lat 90.”, [in:] Kultura i spoteczeństwo na Środkowym Nadodrzu w XIX i XX wieku, P. Bartkowiak, D. Kotlarek (eds.), Pro Libris - Wydawnictwo WiMBP im. Cypriana Norwida w Zielonej Górze, Zielona Góra 2008, pp. 137-148.

Katarzyński J., Dada Rzyje czyli To Co Było Jest i Wcale Nie Musi Być Dada, AND, Zielona Góra 1997.

Katarzyński J., "Kalejdoskop przypadków czyli Art Zine Gallery”, Krzywe Koło Literatury, 1994, issue 5, pp. 8-11.

Klejnocki J., Sosnowski J., Chwilowe zawieszenie broni. O twórczości tzw. pokolenia „bruLionu” (1986-1996), Wydawnictwo Sic!, Warsaw 1996.

Klesyk Ł., "Koniec czasu utopii”, Wiadomości Kulturalne, 1995, issue 25, p. 4.

Koñjo Konnak P., Dzieła zebrane i wylane, CKW, Gdańsk 2009.

Koñjo Konnak P., Gangrena. Mój punk rock song, Narodowe Centrum Kultury, Warsaw 2011.

Koñjo Konnak P., Karnawat profuzji, Narodowe Centrum Kultury, Warsaw 2013.

Kultura niezależna w Polsce 1989-2009, P. Marecki (ed.), Korporacja Ha!art, Krakow 2010.

Lachman M., Gry z ,tandeta” w prozie polskiej po 1989 roku, Universitas, Kraków 2004.

Lampa 2011, issue 3 [monographic issue: Totart].

Ladorucki J., "Brulion jako pismo literackie i kulturalne schyłku XX wieku", Acta Universitatis Lodziensis. Folia Librorum [vol.] 11 (2002), pp. 47-71.

Linie 1988-1994, [reprint from photocopies of Linie magazine from the collection of P. Dunin-Wąsowicz, M. Karcerowicz, A. Wasilkowski, P. Roszczyk], Lampa i Iskra Boża, Warsaw 2005.

Łojas J., Rogozińska A., “Zin”, [in:] Od aforyzmu do zinu. Gatunki twórczości stownej, G. Godlewski, A. Karpowicz, M. Rakoczy, P. Rodak (eds.), Wydawnictwo Uniwersytetu Warszawskiego, Warsaw 2014, pp. 560-569.

Mituś A., Stasiowski P., Rypson P., Agresywna niewinność. Historia grupy Luxus, BWA Wrocław\&Osman Djajadisastra, Wrocław 2014.

"Nike z Biedronki", interview with P. Koñjo Konnak by P. Gołoburda, Lampa, 2009, issue 7-8, pp. 14-37.

Pankowski R., "Kontrkultura w Polsce - Fanziny”, Plastyka i Wychowanie, 1993, issue 4, p. 49.

Pęczak M., "Amatorzy awangardy", Polityka, 1993, issue 47, p. 10.

Pęczak M., Maty stownik subkultur młodzieżowych, Semper, Warsaw 1992.

Puczko K., "Zrób to sam", Ex Libris 1995, issue 83, p. 15.

P.D.W. [P. Dunin-Wąsowicz], "Art Zine Show”, Nowy Nurt, 1995, issue 10, p. 2.

Ratyńska C., "Art zine. Enfant terrible literatury”, Wydawca, 1995, issue 5, pp. $26-27$.

Rerak S., Chtepczac ciekty hel. Histøria yassu, Stowarzyszenie A Kuku Sztuka, Gdynia 2012.

Rostkowski D., "Prasa odlotystów. Fanziny - pisma subkultury", Gazeta Wyborcza, 1993, issue 158, p. 4.

Rudiak R., "Literacka promocja Zielonej Góry pod koniec XX wieku, czyli historia zjawisk artystycznych i wydarzeń kulturalnych”, Studia Zielonogórskie, vol. 19 (2013), pp. 49-95.

Rudiak R., "Trzeci obieg literatury. Artziny w Zielonej Górze i w województwie; Działalność lubuskich organizacji i ugrupowań młodoliterackich”, [in:] Życie literackie na Ziemi Lubuskiej w latach 1945-2000, Pro Libris, Zielona Góra 2015, pp. 284-288, 296-299.

Rypson P., “Dosyć Podporządku!”, Ex Libris, 1994, issue 43, pp. 10-11.

Rypson P., Książki i strony. Polska książa awangardowa i artystyczna w XX wieku, Centrum Sztuki Współczesnej, Warsaw 2000.

Sedeńko W., "Krótkie dzieje fanzinu polskiego", Nowa Fantastyka, 1992, issue 7, pp. 65-67.

Skiba K., Janiszewski J., Koñjo Konnak P., Artyści, wariaci, anarchiści. Opowieść o gdańskiej alternatywie lat 80., Narodowe Centrum Kultury, Warsaw 2011.

Skiba K., Komisariat naszym domem. Pomarańczowa historia, 2nd edition, Narodowe Centrum Kultury, Warsaw 2015. 
Słownik terminów literackich, J. Sławiński (ed.), 3rd edition amended, Zakład Narodowy im. Ossolińskich, Wrocław-Warsaw-Krakow 2000 (entries: "fanziny”, p. 150; "trzeci obieg”, p. 593).

Smoczyński R., "Przyspieszyć koniec świata", [in:] Żadna rozrywka dla chłopaków, Lampa i Iskra Boża, Warsaw 1993, pp. 12-20.

Sobczak J., "O Art Zine Gallery i Art Zine Kongres”, [in:] “Arkusz literacki”, Informator Kulturalny Województwa Zielonogórskiego, 1997, issue 6.

Spontaniczna kultura młodzieżowa. Wybrane zjawiska, J. Wertenstein-Żuławski, M. Pęczak (eds.), Wydawnictwo „Wiedza o Kulturze”, Wrocław 1991.

Spychalski M., "Na straży awangardy - wesołe i ponure wypisy z historii polskiego undergroundu", Odra, 2014, issue 4, pp. 23-31.

Stabro St., "Związki liryki Jacka Podsiadły z tradycją kontrkultury", [in:] Literatura polska 1990_ 2000, T. Cieślak, K. Pietrych (eds.), vol. 1, Wydawnictwo Zielona Sowa, Krakow 2002, pp. 244-279.

Stępień T., “Art-zin”, [in:] Szkolny słownik wiedzy o literaturze. Pojęcia-problemy - koncepcje, R. Cudak, M. Pytasz (eds.), Videograf II, Katowice 2000, pp. 18-22.

Stępkowska M., "III Warszawski Art Zine Show”, Krzywe Koło Literatury, 1995, issue 7, pp. 13-14. Szczepaniak G., "Fanzinowa menażeria", Nowa Fantastyka, 1999, issue 12, p. 74.

Tekieli R., "Fuckty (1)", bruLion, 1989, issue 11-12, pp. 148-168 (reprint: Tekieli R., "Fuckty" [reprint with the consent of R. Tekieli, edited and abbreviated by: M. K. Dziób], Fronda LUX, 2014, issue 72).

Tkaczyk W., "Tęczowe odcienie kontrkultury”, Arkusz, 1995, issue 6, p. 7.

Uglik J., “Artzine’y w Polsce (Rozmowa spreparowana - między Stefanem Pastuszewskim a Jackiem Uglikiem)", Akcent, 2000, issue 4, pp. 16-17.

Varga K., "Białoczerwona alternatywa. (Polski underground literacki opisany w Niemczech)", Gazeta Wyborcza, 1995, issue 172, p. 11.

Varga K., "Powolny schyłek epoki art zinów", Notes Wydawniczy, 1994, issue 11, pp. 36-37.

Varga K., "Trzecia droga, czyli polskie pisma artystyczne w obiegu alternatywnym w latach 80 . i 90.”, [in:] Xerofeeria 2.0. Antologia artzinów. Polskie alternatywne pisma literackie 19802000. Wersja beta, P. Dunin-Wąsowicz, Lampa i Iskra Boża, Warsaw 2002, pp. 4-18.

Varga K., "Wyciskanie pryszcza", Gazeta Wyborcza, 1994, issue 99, p. 8.

Varga K., "Zinowcy są zmęczeni”, Gazeta Wyborcza, 1994, issue 250, p. 10.

"W stanie pierwiastkowym. Rozmowa z W. Kajtochem", interviewer J. Bińczycki, Ha!art, 2011, issue 35/36, pp. 70-76.

Wright F. The History and Characteristics of Zines, part 1-2 [on-line], http://www.zinebook.com/ resource/wright1.html and http://www.zinebook.com/resource/wright2.html or http://zinelibrary.pl/index.php?option=com_content\&view=article\&id=191:-fred-wright-the-history-andcharacteristics-of-zines\&catid=11:o-zinach\&Itemid=3 [accessed on: 10.12.2015].

Xerofeeria. Antologia. Polskie alternatywne pisma artystyczne od $-\infty$ do października 1993. Antologia Art Zinów. - Wyd. dla Art Zine Gallery II, P. Dunin-Wąsowicz, J. Katarzyński, J. Sobczak, A. Wasilkowski (eds.), Lampa i Iskra Boża, Warsaw-Zielona Góra 1993.

Xerofeeria 2.0. Antologia artzinów. Polskie alternatywne pisma literackie 1980-2000. Wersja beta, P. Dunin-Wąsowicz, Lampa i Iskra Boża, Warsaw 2002.

Xerofrenia. Antologia wierszy z tomików wydawanych w obiegu alternatywnym i nie tylko. Antologia nowych wierszy - published for Art Zine Gallery III, selection of poems P. Dunin-Wąsowicz, J. Sobczak, drawings K. May, Lampa i Iskra Boża, Warsaw - Zielona Góra 1994.

Xerofuria. Antologia-katalog. III warszawski Art Zine Show, 20 maja 1995, editing, introduction and notes: P. Dunin-Wąsowicz, Staromiejski Dom Kultury, Warsaw 1995.

"Zin o zinach", J. Bińczycki, Ha!art, 2011, issue 35/36, pp. 65-92.

Żuliński L., “Art Zine Show”, Wiadomości Kulturalne, 1995, issue 25, p. 4. 


\section{Dadaism (Re)activated. Artzins and Dada}

\section{(Summary)}

The article analyses in what way artzins (independent art and literary journals published in Poland in the 1980s and 1990s) drew inspiration from the Dada tradition, and how they made its philosophy live again. Artzins are seen here both as a medium of literature and art and as specific forms of artistic expression (press art). The article attempts to show why artzins and their authors were interested in reviving the avant-garde and Dada ideas. It also investigates how Dadaism functions today in the form of contemporary works and styles which are influenced by this avant-garde movement. What is more, the article tries to answer the question about the nature and definition of Dadaism shaped and reflected by today's artistic projects.

Key words: artzin, Polish counterculture in the 1980s and 1990s, Dadaism 